\title{
An In Vitro Study of Monocyte Phagocytosis in the Peripheral Blood of Healthy and Babesia-Infected Beagles
}

\author{
Tsuyoshi ISHIMINE*, Hideyuki NAGASAWA and Naoyoshi SUZUKI \\ Department of Veterinary Physiology, Obihiro University, \\ Obihiro-shi, Hokkaido 080
}

(Received for publication March 6, 1979)

\begin{abstract}
The monocyte-macrophage cell line is an important marker of the host defense system especially in cell-mediated immunity. This report describes a series of assays that can be applied routinely in canine monocyte function, or phagocytosis and gives some information as to the activation of normal monocytes by sensitized lymphocytes in dogs infected with Babesia gibsoni. Babesia-immune monocytes were more effective in phagocytosis of the parasitized erythrocytes than normal monocytes. Babesia-immune monocytes incubated with Babesia-immune fresh serum showed the highest percentage of phagocytosis. When normal monocytes were incubated for 24 hours with Babesia-immune lymphokines, the percentage of phagocytic monocytes was approximately three times higher than those with normal cultured supernatant.
\end{abstract}

The monocyte-macrophage cell line has several important functions. The major functional properties of monocyte-macrophages are adherence to glass, ingestion or engulfment of particles by pinocytosis or by phagocytosis, involvement in antigen processing and presentation in the afferent limb of the immune response and involvement in the interaction with lymphoid cells in the expression of cell-mediated immune reactions $[3,13,14,20,21]$.

In a series of previous studies by the authors on experimental malaria and toxoplasmosis using rats and mice based on cellmediated immunity, it was reported that macrophage activation was associated with increased cell size, spreading on glass, adhesiveness to a charged surface, phagocytic activity and digestive capacity, and with increase in contents of some lysosomal enzymes $[7,10,11,16-19]$. However, despite the extensive literature on monocytemacrophage physiology, there is a surprising paucity regarding monocyte function in normal dogs and concerning canine diseases with regards to basic and clinical immuno$\operatorname{logy}[4,5,9-12]$.

The authors have undertaken this study to evaluate tests of monocyte function applicable to dogs. This report describes also technics for measuring monocyte phagocytosis and Babesia-protozoan killing.

\section{Materials and Methods}

Babesia species: The strain of Babesia gibsoni [6] used in this study was maintained in the authors' laboratory by beagle passages and kept in a deep freezer at $-180^{\circ} \mathrm{C}$ during the experiments. This was originally obtained from a hunting dog that contracted the parasite in Hyogo Prefecture in Japan.

Experimental animals: Fourteen 90 day-old parasite-free beagles from 3 litters produced by the same parents and maintained in a closed environment

* Present address: Department of Protozoology, Research Institute for Microbial Diseases, Osaka University, Yamada-kami, Suita-shi, Osaka 
were used in the present study. None of them were vaccinated against distemper, rabies and canine hepatitis until the end of the experiment. Three healthy adult beagles, previously inoculated with $B$. gibsoni, five times in 2 years, weighing approximately $15 \mathrm{~kg}$ and harboring no protozoa in the blood, were used as Babesia chronic keagles. They showed IgM and IgG serum antibody titers of 20 and 320 by the indirect immunofluorescent method, respectively. To maintain regular conditions for breeding and feeding, each dog was put in a separate cage and was given a limited volume of standard dog diet everyday. Tap water was supplied ad libitum during the experiment.

Monocyte isolations: The standard Conray-Ficoll cell separation procedure performed in this experiment, yields a band of low density cells comprised mainly of lymphocytes with a small proportion of monocytes [22]. Ten $\mathrm{m} l$ of heparinized blood from the cephalic vein of the dogs was diluted three times with physiological saline solution. Five $\mathrm{m} l$ of blood was added to $2 \mathrm{~m} l$ of Conray-Ficoll (10 vol. of $33.8 \%$ Conray plus $24 \mathrm{vol}$. of $9 \%$ Ficoll) and centrifuged at $1,350 \mathrm{rpm}$ for 20 minutes. Numerous lymphocytes mixed with monocytes in the upper layer of the Conray-Ficoll were collected, washed three times with Hanks' balanced salt solution (HBSS) containing 20\% heat-inactivated calf serum (CS) and then washed again once with medium TC199 containing $40 \%$ CS. For canine monocyte monolayer, $40 \%$ CS is the most suitable concentration which can be added to the medium. Resuspension was made in medium TC-199 with $40 \%$ CS to a concentration of $5 \times 10^{8}$ cells per $\mathrm{m} l$. 'This cell suspension was referred to as "monocyte-lymphocyte" (M-L). To obtain pure monocyte preparations, one $\mathrm{m} l$ of the mononuclear cell suspension was allowed to adhere to a $15 \mathrm{~mm}$ diameter cover slip contained in a plastic culture multidish tray (FB-16-24-TC, Limbro Chem. Co., Inc.) for 5 days in $\mathrm{CO}_{2}$ incubator at $37^{\circ} \mathrm{C}$. One-third of the medium was changed on the first and second day. This was repeated on the 5 th day and every 3 days thereafter. Nonadherent cells were removed by gently washing with warm $\left(37^{\circ} \mathrm{C}\right)$ medium TC-199 with $40 \%$ CSheparin up to the 5 th day. Over $93 \%$ adherent monocytes among the cell monolayers including 1 to $2 \%$ neutrophils were counted.

Preparation of parasitized erythrocytes: Parasitized erythrocytes were collected from the blood of a splenectomized $\mathrm{dog}$ infected with $B$. gibsoni under anesthesia. More than $30 \%$ of the erythrocytes contained the parasites. Blood was collected in sterile Alsever's solution. The erythrocytes were washed 4 times with phosphate-buffered saline
(PBS) and centrifuged at 4,000 $\mathrm{g}$ for 15 minutes after each wash. An amount of PBS was added to the erythrocytes to a concentration of $10^{7}$ parasitized erythrocytes per $\mathrm{m} l$. The erythrocytes were examined as to whether their surface membranes were free from humoral antibodies using the indirect immunofluorescent technic.

Babesia immune fresh serum (BIFS) and Babesiaimmune inactivated serum (BIIS): BIFS and normal fresh serum (NFS) with complement was obtained by venisection into cooled tubes which were immediately centrifuged. The fibrin clot was removed and the serum was stored at $-20^{\circ} \mathrm{C}$ until use. These BIFS and NFS which were incubated in a water bath at $56^{\circ} \mathrm{C}$ for 30 minutes, were termed as inactivated serum containing no complement, that is, BIIS and normal inactivated serum (NIS).

Preparation of Babesia lysate antigen: Three volumes of PBS were added to one packed volume of the parasitized erythrocytes mentioned above. The suspension was homogenized with a glass homogenizer and an ultrasonic vibrator $(100 \mathrm{~W}$, Kubota Insonator, Model 200, Tokyo) and stored for at least 48 hours at $-80^{\circ} \mathrm{C}$. The antigen was thawed, rehomogenized, washed 5 times with PBS and recentrifuged at $17,300 \mathrm{~g}$ for 20 minutes. The final sediment was homogenized with 1.5 vol. of PBS and lyophilized in $0.5 \mathrm{~m} l$ quantities. When needed, $50 \mathrm{mg}$ of lyophilized antigen was mixed with $2 \mathrm{ml}$ of PBS in a $10 \mathrm{~m} l$ conical centrifuge tube and centrifuged at $365 \mathrm{~g}$ for 3 minutes. The supernatant fluid was collected and stored at $-80^{\circ} \mathrm{C}$ as the "Babesia lysate antigen".

Preparation of Lymphokines (LKs): Lymphoid cells in the spleen were collected from normal and Babesia-immune dogs by means of a slight modification of the Conray-Ficoll method (Tsuji, 1971). The cells were washed twice with HBSS. Normal and Babesia-immune spleen lymphoid cell suspensions were incubated with $50 \mu \mathrm{g}$ Babesia lysate antigen in a humidified $5 \% \mathrm{CO}_{2}$ incubator at $37^{\circ} \mathrm{C}$ for 24 hours. These lymphoid cell cultures were centrifuged at $1000 \mathrm{~g}$ for 30 minutes. The supernatants thus obtained were filtered through a millipore membrane filter $(0.3 \mu \mathrm{m}$, type $\mathrm{PH}$, Millipore Co., Mass.) and were used as the normal cultured supernatant and Babesia-immune lymphokines (LKs). They were diluted 1:2 with medium TC-199.

Phagocytosis: The monocytes which adhered on the cover slips contained in the plastic culture dishes were incubated with $0.5 \mathrm{~m} l$ NFS or BIFS in $1.0 \mathrm{ml}$ medium TC- 199 with $40 \% \mathrm{CS}$ at $37^{\circ} \mathrm{C}$ for 30 minutes. The monocyte monolayers were incubated with $0.5 \mathrm{~m} l$ NIS or BIIS which were pretreated at $56^{\circ} \mathrm{C}$ for 30 minutes, with $1.0 \mathrm{~m} l$ medium TC-199 
Table 1. Differential percentages of monocytes and other leukocytes in the peripheral blood of beagle and mongrel dogs using the Conray-Ficoll cell separation method

\begin{tabular}{|c|c|c|c|c|c|c|}
\hline \multirow[b]{2}{*}{ Species } & \multirow{2}{*}{$\begin{array}{c}\text { No. of cases } \\
\text { tested }\end{array}$} & \multirow{2}{*}{$\begin{array}{l}\text { Conray-Ficoll } \\
\text { method }\end{array}$} & \multicolumn{4}{|c|}{ Mean percentage of the differentiated leukocytes } \\
\hline & & & $\begin{array}{c}\text { Monocytes } \\
\text { Mean } \pm S D \text { range }\end{array}$ & $\begin{array}{c}\text { Lympocytes } \\
\text { Mean } \pm S D \text { range }\end{array}$ & $\begin{array}{c}\text { Neutrophils } \\
\text { Mean } \pm S D \text { range }\end{array}$ & $\begin{array}{c}\text { Others } \\
\text { Mean } \pm S D \text { range }\end{array}$ \\
\hline \multirow[t]{2}{*}{ Beagle } & 10 & Before & $4.3 \pm 1.3(2-6)$ & $18.4 \pm 1.6(15-20)$ & $74.7 \pm 2.4(71-78)$ & $2.6 \pm 0.7(2-4)$ \\
\hline & 10 & After & $5.6 \pm 1.5(4-8)$ & $85.3 \pm 4.3(81-93)$ & $6.8 \pm 2.9(2-10)$ & $2.3 \pm 1.1(1-4)$ \\
\hline \multirow[t]{2}{*}{ Mongrel } & 10 & Before & $4.2 \pm 1.0(3-6)$ & $33.4 \pm 4.1(27-37)$ & $57.4 \pm 3.8(53-63)$ & $5.0 \pm 1.4(3-7)$ \\
\hline & 10 & After & $2.8 \pm 1.1(1-5)$ & $91.1 \pm 5.6(81-96)$ & $2.6 \pm 3.2(0-9)$ & $3.5 \pm 3.1(0-8)$ \\
\hline
\end{tabular}

Table 2. Phagocylic percentages of the parasitized erythrocytes in monocytes from normal and Babesia chronically infected beagles

\begin{tabular}{|c|c|c|c|c|c|c|}
\hline \multirow{3}{*}{$\begin{array}{l}\text { Minutes after } \\
\text { addition of erythrocytes }\end{array}$} & \multicolumn{6}{|c|}{ Phagocytic percentages of the parasitized erythrocytes in* } \\
\hline & \multicolumn{3}{|c|}{ Normal monocytes } & \multicolumn{3}{|c|}{ Babesia-immune monocytes } \\
\hline & 30 & 60 & 120 & 30 & 60 & 120 \\
\hline \multicolumn{7}{|l|}{ Incubation with } \\
\hline Inactivated normal serum** & 9.4 & 10.0 & 16.0 & 26.0 & 29.0 & 28.8 \\
\hline Fresh normal serum & 13.6 & 13.0 & 37.8 & 18.6 & 26.2 & 29.7 \\
\hline Inactivated immune serum** & 18.0 & 24.0 & 28.5 & 35.7 & 43.7 & 33.4 \\
\hline Fresh immune serum & 21.4 & 24.6 & 30.9 & 56.6 & 41.4 & 59.7 \\
\hline
\end{tabular}

Remarks.

* Average were calculated from 5 independent experiments.

** Fresh serum was inactivated at $56^{\circ} \mathrm{C}$ for 30 minutes.

with $40 \% \mathrm{CS}$ at $37^{\circ} \mathrm{C}$ for 30 minates. One $\mathrm{ml}$ of the parasitized erythrocyte suspension was added to each of these monocyte monolayers. The cover slips were taken from the culture dishes and stained with May-Grünwald and Giemsa at 30,60 and 120 minutes after incubation [15]. Phagocytized erythrocytes ingested by 500 monocyles were counted to get the mean phagocytized parasites per monocyte.

\section{Results}

The results of monocyte isolation, as shown in Table I, were collected from $10 \mathrm{~m} l$ of heparinized blood. This volume was sufficient to perform the full battery of the assays described with M-L suspension making monocyte monolayers and lyphocyte products or LKs.

Before Conray-Ficoll cell separation, the mongrel dog blood contained 3 to $6 \%$ monocytes (4.2 \pm 1.0$), 27$ to $37 \%$ lymphocytes

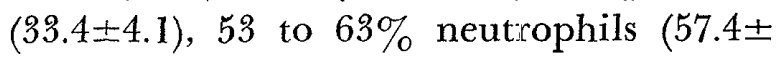

3.8 ) and 3 to $7 \%$ other cells $(5.0 \pm 1.4)$. After separation, the separated M-L suspension from the same mongrel dog contained 1 to $5 \%$ monocytes $(2.8 \pm 1.1), 81$ to $96 \%$ lymphocytes $(91.1 \pm 5.6), 0$ to $9 \%$ neutrophils

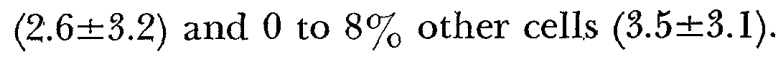
Before separation, the beagle dogs had a range and mean percentage of 2 to $6 \%$ monocytes $(4.3 \pm 1.3), 15$ to $20 \%$ lymphocytes

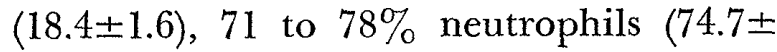
$2.4)$ and 2 to $4 \%$ other cells $(2.6 \pm 0.7)$. The separated M-L suspension from the same beagles contained 4 to $8 \%$ monocytes (5.6士 $1.5), 81$ to $93 \%$ lymphocytes (85.3 44.3$), 2$ to $10 \%$ neutrophils $(6.8 \pm 2.9)$ and 1 to $4 \%$ other cells $(2.3 \pm 1.1)$. There was a significant difference in the percentage of lymphocytes and neutrophils in the separated suspension and non-separated blood of both mongrel and beagle dogs.

As shown in Table 2, phagocytic percen- 
Table 3. Phagocytic percentages of the auto- and iso-erythrocytes in monocytes from normal and Babesia chronically infected beagles

\begin{tabular}{|c|c|c|}
\hline \multirow{2}{*}{$\begin{array}{l}\text { Minutes after addition of } \\
\text { non-parasitized erythrocytes }\end{array}$} & \multicolumn{2}{|c|}{ Percentages of erythrocyte phagocytosis* } \\
\hline & $\begin{array}{c}\text { Normal monocytes } \\
30\end{array}$ & $\begin{array}{l}\text { Babesia-immune monocytes } \\
30\end{array}$ \\
\hline \multicolumn{3}{|l|}{ Iso-erythrocytes with } \\
\hline inactivated normal serum** & 9.4 & 14.1 \\
\hline fresh Babesia-immune serum & 8.2 & 11.7 \\
\hline Auto-erythrocytes with & \multirow[b]{2}{*}{10.0} & \\
\hline inactivated normal serum** & & \\
\hline fresh Babesia-immune serum & & 8.2 \\
\hline \multicolumn{3}{|c|}{$\begin{array}{l}\text { Remarks. } \\
\text { * Averages were calculated from } 4 \text { independent experiments. } \\
\text { * Fresh serum was incubated at } 56^{\circ} \mathrm{C} \text { for } 30 \text { minutes. }\end{array}$} \\
\hline \multicolumn{3}{|c|}{$\begin{array}{l}\text { Table 4. Induction of phagocytic activity in normal peripheral monocytes } \\
\text { following incubation for } 24 \text { hours with lymphokines }\end{array}$} \\
\hline \multicolumn{2}{|c|}{$\begin{array}{l}\text { Non-immune monocyles were cultured } \\
\text { for } 24 \text { hours with supernatants from }\end{array}$} & $\begin{array}{l}\text { percentage of monocytes* } \\
\text { oarasitized erythrocytes } \\
\text { urs after addition) }\end{array}$ \\
\hline \multicolumn{2}{|l|}{$\begin{array}{l}\text { Normal beagle spleen cells } \\
\text { + Babesia antigen }\end{array}$} & $5.6 \pm 1.3$ \\
\hline \multicolumn{2}{|l|}{$\begin{array}{l}\text { Babesia-immune spleen cells } \\
\text { + Babesia antigen }\end{array}$} & $14.1 \pm 2.2$ \\
\hline
\end{tabular}

tages of the parasitized erythrocytes in normal monocyte monolayers incubated with NIS at 30, 60 and 120 minutes incubation were $9.4,10.0$ and 16.0, respectively. In normal monocytes incubated with NFS, the percentages of phagocytosis were 13.6, 13.0 and 37.8 at 30,60 and 120 minutes incubation. The positive rate of normal monocytes ingesting parasitized erythrocytes increased to $18.0,24.0$ and 28.5 per cent, 30 , 60 and 120 minutes after adding BIIS. By addition of BIFS to normal monocytes at 30,60 and 120 minutes incubation, the phagocytosis in the monocytes increased remarkably to $21.4,24.6$ and 30.9 per cent as compared with those in NIS. When immune monocytes were added to NIS, however, they engulfed parasitized erythrocytes by phagocytosis with percentages of 26.0,
29.0 and 28.8 at 30,60 and 120 minutes incubation. With the addition of BIFS, the phagocytic ability of immune monocytes increased remarkably to 56.6 per cent 30 minutes after incubation. Immune monocytes incubated with BIFS for 120 minutes had the highest percentage $(59.7 \%)$ of ingestion of parasitized erythrocytes.

To determine the phagocytosis of nonparasitized erythrocytes by normal or immune monocytes as shown in Table 3, NFS or BIFS with iso-erythrocytes and auto-erythrocytes were added to normal and immune monocyte monolayers. In normal monocytes incubated with either NIS or BIFS, the percentage of monocytes ingesting iso-erythrocytes or auto-erythrocytes were $9.4,8.2$ or 10.0 , thirty minutes after addition of the erythrocytes. Immune monocytes in- 
cubated with the same conditions as in normal monocytes phagocytosed $14.1 \%$ isoerythrocytes and $8.2 \%$ auto-erythrocytes.

The data in Table 4 showed the enhancement effect of the LKs on phagocytosis of parasitized erythrocytes by normal monocytes two hours after the introduction of the infected erythrocytes. When normal monocytes were incubated for 24 hours with the Babesia-immune LKs which were produced by the immune lymphocytes and the specific antigen, the percentage of phagocytic monocytes was approximately 14 , as compared with that of normal cultured supernatant showing 5.6.

\section{Discussion}

The major functional properties of monocytes are adherence to glass with surface receptors on the plasma membrane of the cells, ingestion and engulfment of foreign bodies by pinocytosis and phagocytosis, cytotoxicity and metabolic activity. Phagocytosis and Babesiacidal killing properties were chosen because these functions give a basic insight into the host defense status and to the degree of activation of the monocytes. Both are crucial elements in the mammalian host defense system.

Monocytes obtained from immune dogs exhibited enhanced function when cultured in vitro. They appeared more spread out on slide cover glass and more phagocytic showing enhanced Babesiacidal. activity. The in vivo state of activation of monocytes obtained from dogs undergoing an active infection can be simulated in vitro by exposing monocytes from normal individuals to lymphocyte mediators, LKs. It was shown in mice and rats that normal macrophages could be activated after 24 hours incubation with Toxoplasma or Plasmodium immune LKs [7, 10, 11, 17-19]. In previous reports by the authors on protozoan im- munity of Toxoplasma, non-immune macrophages infected with $T$. gondii in vitro, possessed the ability to inhibit the multiplication of intracellular Toxoplasma either by co-cultivation with immune lymphocytes or by the addition of the LKs present in the supernatant fluids from immune lymphocytes cultured with Toxoplasma specific antigen or non-specific mitogens $[10,11$, 16-19].

The erythrocyte phagocytic activity of normal monocytes, 30 to 120 minutes after the addition of the parasitized erythrocytes was shown to be in the range of 5.6 to 16.0 in this experiments. The difference of the phagocytic percentage in the normal monocytes might be caused by using the parasitized erythrocytes in the different status and also by some mechanical damages which were due to thorough washing with PBS. However, the erythrocyte phagocytic activity of normal monocytes was very weak in every experiment as compared with those of activated monocytes which were done in the same condition. Babesia-immune monocytes with BIFS were the most efficient in the ingestion of parasitized erythrocytes. As for the phagocytosis of Babesia-parasitized erythrocytes by normal beagle monocytes with the addition of LKs incubated for 24 hours, the phagocytic activity in the monocyte was more enhanced as compared with that of normal cultured supernatant. In the study conducted by Rosse [13, 14], the reactions of monocytes with erythrocytes covered with complement only or with antibody only were investigated. When erythrocytes were coated with complement, they readily adhered to the surface of the phagocytic cells faster than that with antibody only. These phenomena were also compatible with the observations of Criswell [2] and Makimura [7] in experimental malaria. Brown [1] observed also in vitro 
that macrophages from BCG-infected mice phagocytosed Plasmodium knowlesi infected erythrocytes more readily than macrophages from normal mice in the presence of specific antibody. The cooperative mechanism to the monocytes between LKs and BIFS has not been clarified yet. However, taken together with the present data, it is clear that monocyle phagocytic activity in the status of activated monocytes by the addition of Babesia-immune LKs was more enhanced by the adherence of the parasitized erythrocytes with addition of BIFS. The phagocytic phencmena in the canine monocytes in vitro system from the observed results are very likely similar to the mechanism for ingestion by phagocytes, generally called opsonization.

Acknowledgments: The authors wish to express their thanks to Dr. George E. Lewis and Prof. Dr. M. Ristic, Department of Pathology and Hygiene, College of Veterinary Medicine, University of Illinois, USA, for their valuable assistance irı the differential examination for B. canis, B. gibsoni and $E$. canis.

\section{References}

[1] Brown, K. N. (1971). Protective immunity to malaria provides a model for the survival of cell in an immunologically hostile environ. ment. Nature 230, 163-167.

[2] Criswell, B. S., Butler, W. T., Rossen, R. D., and Knight, V. (1971). Murine malaria. The role of humoral factors and macrophages in destruction of parasitized erythrocytes. J. Immunol. 107, 212-221.

[3] Fudenberg, H. H., Stites, D. P., Caldwell, J. L., and Wells, J. V. (1976). In Basic and Clinical Immunology, Lange Med. Pub., Maruzen Asian Co., Tokyo, 587-595.

[4] Groves, M. G. (1972). Babesia gibsoni field and laboratory studies of canine infections. Exp. Parasit. 31, 153-159.

[5] Ishimine, T., Makimura, S., Kitazawa, S., Tamura, S., and Suzuki, N. (1978). Pathophysiological findings on blood of: beagles experi- mentally infected with Babesia gibsoni. Jap. trop. Med. Hyg. 6, 15-26.

[6] Lewis, G. E., and Ristic, M. (1977). Personal communication.

[7] Makimura, S., and Suzuki, N. (1977). Studies on the phagocytosis of parasitized erythrocytes from mice experimentally infected with Plasmodium berghei by mouse peritoneal macrophages. Res. Bull. Obihiro Univ. 10, 401-406.

[8] Nelson, D. S. (1976). In Immunobiology of the Macrophage, Academic Press, New York, USA, 291-320.

[9] Noda, R. (1977). Canine babesiosis. J. Japan vet. med. Ass. 30, 247-251 (in Japanese).

[10] Noda, S., and Suzuki, N. (1977). Influence of lymphokines and macrophage inducers on the mouse peritoneal macrophages. Jap. J. Parasit. 26 (Suppl.), 25 (in Japanese).

[11] Noda, S., and Suzuki, N. (1978). Effects of macrophage inducers and lymphokines obtained from mice immunized with the virulent strain of $T$. gondii on the function of mouse peritoneal exudate macrophages. $J$. development. comparat. Immunol. 2 (in press).

[12] Ristic, M., Lykins, J. D., and Smith, A. R. (1971). Babesia canis and Babesia gibsoni. Soluble and corpuscular antigen isolated from blood of dogs. Exp. Parasit. 30, 385-392.

[13] Rosse, W. F., and Boisfleury, A. (1975). The interaction of phagocytic cells and red cells following alteration of their form or deformability. Blood Cells 1, 359-367.

[14] Rosse, W. F., Boisfleury, A., and Bessis, M. (1975). The interaction of phagocytic cells and red cell modified by immune reactions. Comparison of antibody and complement coated red cells. Blood Cells 1, 345-358.

[15] Scott, F. W., Csiza, C. K., and Gillespie, J. H. (1970). Feline viruses. V. Serum-neutralization test for feline panleukopenia. Cornell vet. 60, 183-191.

[16] Sethi, K. K., Pelster, B., Suzuki, N., Piekarski, G., and Brandis, H. (1975). Immunity to $T$. gondii induced in vitro in non-immune mouse macrophage with specifically immune lymphocytes. J. Immunol. 115, 1151-1158.

[17] Shirahata, T., Shimizu, K., Noda, S., and Suzuki, N. (1977). Studies on production of biologically active substance which inhibits the intracellular multiplication of Toxoplasma within mouse macrophages. Z. Parasitenk. 53, $31-40$.

[18] Shirahata, T., Shimizu, K., and Suzuki, N. (1975). An in vitro study on lymphocyte mediated immunity in mice experimentally in- 
fected with T. gondii. Jap. J. vet. Sci. 37, 235243.

[19] Shirahata, T., Shimizu, K., and Suzuki, N. (1976). Effects of immune lymphocyte products and serum antibody on the multiplication of Toxoplasma in murine peritoneal macrophages. Z. Parasitenk. 49, 11-23.

[20] Snyderman, R., Pike, M. C., Fisher, D. G., and Koren, H. S. (1977). Biologic and biochemical activities of continuous macrophage cell lines
P 388D and J774. J. Immunol. 119, 2060-2066.

[21] Territo, M., and Cline, M. J. (1977). Monocyte function in man. J. Immunol. 118, 187192.

[22] Tsuji, K. (1971). Separation of lymphocytes by using the Conray 400-Ficoll method. Cell Immunology 1, 265-268 (in Japanese).

[23] Vernon-Robert, B. (1972). In The Macrophage, Cambridge University Press, England, $148-182$.

要 約

健康およびバベシア原虫感染ビーグル末梢血波中単球の貪食性について：石嶺 毅（大服大学微生物 病研究所原虫部門), 長沢秀行・鈴林直義 (带広畜産大学家畜生理学教室) 一一細胞性免疫現象は特異的 に感作されたリンハ球と，これによって活性化されたマクロフアージあるいは感作リンパ球産生物質 （リンホカイン）などが相互に関与しているものと考えられている。これらは，in vitro で解析する研 究方法が確立されだして，その機㜿が徐々に明らかになりつつある。しかしながら，犬に执いての報告 は殆んど見当らない，そこで，in vitro 培養によるビーグルの末梢血液中単球を用いて，バベシア原虫 感作リンパ球産生物質，リンホカインが単球におよはす影響を領食能の面から検討を加えた．犬末梢血 液中単球の単層培養作成には，40\% 仔牛血清添加培養液を用いて，5 日間前培養をおこない，試験に供 した．バベシア原虫感染慢性犬から採取した単球（バベシア免疫単球）と健康ビーグルからの単球（正 常単球）にバベシア含有赤血球を添加して30分後の貪食率を求めると，それぞれ $26 \%$ および $9.4 \%$ で あった：これらの培養層中に，バ心゙シア免疫新鮮血清を投与すると，それぞれの貪食率は $56.6 \%$ 打よ び $21.4 \%$ に增加した. 正常単球疷バベシア免疫リンホカインあるいは正常りンパ球培㽰上清と共に24 時間培養されて後，バベシア原虫含有赤血球を単球培養層に添加した．添加後 2 時間での単球の赤血球 食食率は，それぞれ $14.1 \%$ 拈よび $5.6 \%$ で，正常単球の實食性は免疫リンホカイン添加培養により約 3 倍立進した。 